\title{
Material Flow Analysis and Resource Recovery Potential Analysis of Selected Fruit, Vegetable and Nut Waste in Kenya
}

Steven De Meester ( $\sim$ steven.demeester@ugent.be )

Ghent University: Universiteit Gent https://orcid.org/0000-0002-5246-3918

Benson Dulo

University of Ghent: Universiteit Gent https://orcid.org/0000-0002-4815-4469

John Githaiga

Moi University School of Engineering https://orcid.org/0000-0002-4172-4756

Katleen Raes

Ghent University: Universiteit Gent

\section{Research Article}

Keywords: Kenyan bio-waste, valorisation, banana, coconut, potato, Material Flow Analysis

Posted Date: September 20th, 2021

DOI: https://doi.org/10.21203/rs.3.rs-886139/v1

License: () (1) This work is licensed under a Creative Commons Attribution 4.0 International License. Read Full License 


\section{Abstract}

In Kenya, agriculture is an important economic activity, which implies that a significant amount of bio-waste is generated. This is on one hand a waste management problem, but on the other hand, it is an opportunity for creating a sustainable bioeconomy. Therefore, this study investigates the potential recovery of bioresources from Kenyan bio-waste. The study first quantifies occurrence, current usage and disposal of three selected biomass types, being banana, potato and coconut waste. Next, material flow analysis (MFA) is used to systematically track the mass flow of these wastes. Finally, the potential of biomolecules, biomaterials and bioenergy from the waste streams is evaluated. The study revealed that 6007,426 and $49.5 \mathrm{kt}$ of banana, potato and coconut biomass is wasted. All these wastes can be biorefined, offering potential towards recovery of; flavonoids (88.3 kt), starch (377 kt), cellulose (2000.7 kt) and biogas $(1757.0 \mathrm{GWh})$, being the total potential of the main bioresources from the three waste streams. The study therefore, concluded that, with proper waste collection, sorting and valorisation, there is a huge potential for bioeconomy in Kenya, at the same time reducing waste management problems.

\section{Statement Of Novelty}

Resource recovery potential analysis is performed on Kenyan fruits, vegetable and nut wastes. With proper waste collection, sorting and valorisation, there is a huge potential for improved bioeconomy in Kenya and similarly to many other (developing) countries, at the same time reducing waste management problems. In Kenya, and in broader sense, many developing countries, where agriculture is a key economic activity, implying that a significant amount of biowaste is generated, there is no waste mapping or systematic study due to lack of data collected on the agricultural and food waste generation and destination. Limited literature that exist, however, show that the wastes are generally not valorized, despite the potential of recovering a high value bioresource from the waste streams. The paper also evaluates the logistics of the bioresource recovery.

\section{Introduction}

In the year 2019, around 8 million tons of solid waste was generated in Kenya and the rate of generation is likely to double by the year 2030 , driven by socioeconomic development and rapid population growth [1]. Between 2009 and 2019, the country's population increased by an average of 1 million people annually, while at the same time, Kenya achieved a middle-level income status, which resulted into an increasing demand for food and other resources [2]. Further, this implies that a significant amount of bio-waste is generated. To alleviate these challenges, efforts should focus on resource efficiency and circular economy. This would imply that resources are used efficiently throughout all stages of their lifecycle and throughout the supply chain, by emphasizing minimizing waste or transforming them into high quality secondary raw materials [3-5].

In Kenya, and similarly to many other (developing) countries, these bio-wastes are often burned or disposed of in open landfills, directly leading to environmental pollution and to climate change through particulate and greenhouse gas (GHG) emissions. Furthermore, due to prevalent tropical climate, the pile of bio-waste often becomes a habitat to pests and rodents and hence becomes a nuisance with corresponding health implications [6].

Since agriculture is the main economic activity in Kenya, contributing directly and indirectly to over 50\% of the country's gross domestic product (GDP) and providing livelihoods to over $80 \%$ of the entire population, the sector is expected to generate high quantity of bio-wastes [7]. Indeed, according to research conducted in Kenya, organic wastes from urban markets alone (excluding waste or inedible parts that remains at the farm gate and collection centers), forms over $4,000 \mathrm{kt}$ representing over $50 \%$ of all wastes produced in the urban centers per year [8]. However, despite the high quantity of these types of waste and their related environmental and health hazards, the rate of valorization is just about $40 \mathrm{kt}$ accounting for about $1 \%$ of the total urban organic waste alone per year, thus, bio-wastes is a key contributor to waste management problem in Kenya $[8,1,6]$. This can be ascribed to the dispersity of waste generation, but also, there seems to be little knowledge about the potential benefits of waste valorization. In cases where these wastes are utilized, they are turned into relatively low added value products such as mulch, compost, energy (by burning) or in best case scenario, as animals feed $[8,9]$.

At a policy level, Kenya adopted the "Transforming our world: the 2030 Agenda for Sustainable Development", which aims to make the human environment safe, resilient and sustainable, ensuring sustainable production and consumption patterns and also reducing GHG emission by $30 \%$ by 2030 under the United Nation (UN) Framework Convention on Climate Change [1]. Strategic decisions now have to be made on how to achieve these targets. Science could support interventions towards an effective conversion of wastes from the food chain to usable, preferably high-valued products.

As a starting point for policy implementation in this context, mapping of the situation of these wastes should be performed, including current quantities, origin and destinations. One of the tools that can be used for this purpose is Material Flow Analysis (MFA). Indeed, MFA has been used for the analysis of organic waste flow in amongst others, Europe [10], UK [11], US [12], Asia [13] and proven to be useful in the support of organic waste management and recycling policies by allowing visualization and quantification of flows that are to be managed. Nevertheless, agricultural and food waste generation and destination in Kenya, and in broader sense, many developing countries still lacks mapping as there is no systematically collected data. There is, however, a bit of unpublished literature, sometimes in local languages, and some other local information which is generally not accessible to a broad audience [14].

Within this specific Kenyan context, the main objective of this research is to study the potential of bioresource material recovery from selected Kenyan agricultural-based waste. This paper identifies quantity, occurrence, current usage and disposal trends of the most important fruit, vegetable and nut waste streams in Kenya. The information is summarized in a comprehensive MFA, to track the mass flow of selected waste streams from production through processing, consumption and disposal. Finally, the potential bioresource materials recoverable from the waste streams and the logistics of recovery are evaluated.

\subsection{Preface: selection of case study}


Within this study, a broad inventory of fruit, vegetable and nut wastes quantities in Kenya was made that informed the selection of different case studies for the valorization potential of the waste streams. Apart from the waste quantities, the case studies were also selected based on their inherent differences,

including, dry versus wet waste, soil grown vis-a-vis above ground (tree) based wastes. Table 1 gives an overview of top ten fruit, vegetable and nut wastes in Kenya. Based on this inventory, we selected banana, potato and coconut waste as case studies, for each of these groups. In Table 1 , the potential quantity of waste (column 7) is derived from the production quantity (column 5) and the potential waste proportion (column 6) found in literature. 
Table 1

Top ten fruits, vegetable, and nuts in in Kenya in the year 2018

\begin{tabular}{|c|c|c|c|c|c|c|}
\hline $\begin{array}{l}\text { Product } \\
\text { class }\end{array}$ & $\begin{array}{l}\text { Production } \\
\text { Rank }\end{array}$ & Agricultural product & Nature of waste & $\begin{array}{l}\text { Production in } \\
\text { Kenya }_{\mathrm{FW}}(\mathrm{kt})[15]\end{array}$ & $\begin{array}{l}\text { Approximate } \\
\text { potential waste } \\
(\%)\end{array}$ & $\begin{array}{l}\text { Derived potential } \\
\text { quantities of waste (kt) } \\
\text { FM }\end{array}$ \\
\hline \multirow[t]{10}{*}{ Fruits } & 1 & $\begin{array}{l}\text { Bananas (plantain, } \\
\text { dessert and other) }\end{array}$ & $\begin{array}{l}\text { Pseudostem, peel, stock, } \\
\text { leaves, bud, rotten pulp }\end{array}$ & 1447 & $88^{e, f}$ & 1273 \\
\hline & 2 & $\begin{array}{l}\text { Mangoes, Mangosten, } \\
\text { Guavas }^{a}\end{array}$ & $\begin{array}{l}\text { Pomace, peel, stone/seed, } \\
\text { seed coat }\end{array}$ & 676 & $47^{f}$ & 318 \\
\hline & 3 & Tomato $^{a}$ & Pomace, cull tomato & 599 & $20^{g}$ & 120 \\
\hline & 4 & Pinneaples ${ }^{a}$ & Pomace, peel, crown & 349 & $46^{f}$ & 161 \\
\hline & 5 & Avocado $^{a}$ & $\begin{array}{l}\text { Pomace, peel, stone, seed } \\
\text { coat }\end{array}$ & 234 & $26^{f}$ & 61 \\
\hline & 6 & Water melon ${ }^{a}$ & Peel, seed/rind & 189 & $48^{f}$ & 91 \\
\hline & 7 & Papaya $^{a}$ & Pomace, Peel, seed & 134 & $47^{f}$ & 63 \\
\hline & 8 & Fruit citrus nes ${ }^{a}$ & Pomace, peel, seed & 84 & $34^{f}$ & 29 \\
\hline & 9 & Oranges $^{a}$ & Pomace, peel, seed & 72 & $24^{f}$ & 17 \\
\hline & 10 & $\begin{array}{l}\text { Fruit tropical fresh } \\
\text { nes }^{a}\end{array}$ & $\begin{array}{l}\text { Peel, seed/stone, rind, skin, } \\
\text { pomace }\end{array}$ & 39 & $27^{f}$ & 11 \\
\hline \multirow[t]{10}{*}{ Vegetable } & 1 & Irish Potatoes ${ }^{b}$ & Peel & 1870 & $16^{f}$ & 299 \\
\hline & 2 & Cassava $^{b}$ & Peel & 946 & $28^{h}$ & 265 \\
\hline & 3 & Sweet potatoes ${ }^{b}$ & Peel & 871 & $22^{f}$ & 192 \\
\hline & 4 & Beans, dry ${ }^{c}$ & $\begin{array}{l}\text { Hull, germ powder, husk, } \\
\text { Broken grain }\end{array}$ & 837 & $18^{g}$ & 151 \\
\hline & 5 & $\begin{array}{l}\text { Cabbages and other } \\
\text { brassicas }^{a}\end{array}$ & Trim losses & 674 & $20^{f}$ & 135 \\
\hline & 6 & Vegetables, fresh nes ${ }^{a}$ & Trim losses & 670 & $20^{f}$ & 134 \\
\hline & 7 & Spinach $^{a}$ & Trim losses & 169 & $20^{f}$ & 34 \\
\hline & 8 & Pigeon peas ${ }^{c}$ & $\begin{array}{l}\text { Hull, germ powder, } \\
\text { husk, Broken grain }\end{array}$ & 86 & $40^{g}$ & 34 \\
\hline & 9 & Onions, dry ${ }^{b}$ & $\begin{array}{l}\text { Outer leaves, tunic, basal } \\
\text { plate, roots }\end{array}$ & 35 & $11^{f}$ & 4 \\
\hline & 10 & Beans green ${ }^{c}$ & Pods & 34 & n.d & - \\
\hline \multirow[t]{10}{*}{ Nut } & 1 & Coconuts $^{c}$ & Shell, husk & 105 & $47^{i}$ & 49 \\
\hline & 2 & Macadamia (nut nes) ${ }^{c}$ & Shell & 27 & $40-45 j$ & 11 \\
\hline & 3 & Groundnuts $^{\mathrm{d}}$ & Shell, karnel & 21 & $25^{\mathrm{j}}$ & 5 \\
\hline & 4 & Cashew nuts ${ }^{c}$ & Shell & 14 & $55-65^{j}$ & 8 \\
\hline & 5 & Bambara nut & Shell & 3.4 & & \\
\hline & 6 & Areca nuts ${ }^{c}$ & Shell, husk & 0.1 & $60-80^{j}$ & 0.7 \\
\hline & 7 & $\begin{array}{l}\text { Nutmeg, mace and } \\
\text { cardamoms }^{c}\end{array}$ & Shell, seed & 0.06 & - & - \\
\hline & 8 & Chestnut $^{\mathrm{C}}$ & Shell & n.d & $25^{\mathrm{k}}$ & - \\
\hline & 9 & Walnut $^{\mathrm{C}}$ & kernel, green husk, shell & n.d & $67^{1}$ & - \\
\hline & 10 & Hazel nut ${ }^{c}$ & Shell & n.d & $67^{i}$ & - \\
\hline
\end{tabular}

${ }^{a}$ Wet, on ground waste (tree), ${ }^{b}$ Wet, underground waste, ${ }^{c}$ dry on ground waste, ${ }^{d}$ dry underground waste, e [16], ${ }^{f}[17],{ }^{g}$ [18] h [19], ${ }^{\prime}[20],{ }^{j}[15],{ }^{k}[21],{ }^{i}[22]$, n.d: not determined 
Banana is a herbaceous plant in the genus Musa and family Musaceae and is cultivated mainly for its fruit [23]. Banana plants consist of a rhizome (corm), a succulent stem called pseudostem, leaves, and a stock (rachis or peduncle) which supports an oval inflorescence consisting of deep purple waxy bracts (male bud) enclosing the female and male flowers in the lower and upper rows respectively. The female flowers eventually develop into banana fruits (hand). The fruits are harvested after every four to six months of planting [24] and are normally covered by a thick skin (peel) which is peeled off to expose the edible part (pulp). Except for the pulps and sometimes the rhizomes, all parts of the banana plant are potential waste [23]. These potential by-products are about $88 \%$ of the whole banana plant [16] which translate to an estimated $0.22 \mathrm{kt}$ of waste per hectare in countries such as India, where the average yield of banana is about 30 t per hectare [25].

In Kenya, banana is the most important fruit in terms of productivity and is available throughout the year. For example, in 2017, banana fruits accounted for about $14.5 \%$ of the total value of horticulture and $35.9 \%$ of all fruits produced [26]. Typically, there are two cultivars of bananas in Kenya namely the desert (Musa sapientum) - the ripe edible cultivar and the plantain (Musa paradisiaca) - the cooking cultivars [27]. The two cultivars generally have similar morphology and are generalized as bananas [27] and will be considered so in this study.

Irish potato (Solanum tuberosum L.), is a root vegetable in the family of Solanaceae and genus Solanum. Due to its high nutritional value and adaptability to different climates, Irish potato tuber is the second most important staple food and strategic security crop in Kenya after maize and accounts for about $50 \%$ by volume of all vegetables produced and approximately $23.5 \%$ by value of the horticultural produce $[28,29]$. It is grown by around 800,000 farmers who retain around $10 \%$ of their produce as seed potato and sell the rest mainly at local markets [30,31]. Annually, about 1.5 to 2 million tonnes of potatoes are produced mostly by a few large-scale farmers and many small-scale farmers [32, 29]. Irish potato plants consist of stems, branches, leaflets, roots, auxiliary buds, flowers and an enlarged portion of the stolon called tubers. Maturity is characterized by dehauliming, senescence or vine desiccation involving stem, branches and leaves yellowing or turning brownish and eventually drying and dropping off or being mechanically removed to allow tuber skin to harden and reduce damage to the tubers during harvesting $[33,29]$. The main part that remains after desiccation is the tuber, of which during harvesting and subsequent processing, generates rotten/rejected tubers and peels as the main potential wastes comprising about $25 \%$ and $12 \%$ of the total potato production respectively $[32,34]$.

Apart from farm gate production wastes for both bananas and Irish potatoes, further wastes is generated during transportation, packaging, storage, sales and consumption due to, among other factors, adverse weather effects such as temperatures, poor road networks etc.) [35]. Furthermore, rejects are created due to attacks by pests and diseases, damage or inefficiencies during harvesting and processing, or as a result of over-supply and competition [27, 35, 36].

Cocos nucifera L. is a palm tree that belongs to the family Arecaceae and genus Cocos. The coconut palm tree produces a nut referred to as 'coconut' and is the highest productive nut in Kenya and accounted for over $58 \%$ of productivity of all nuts in 2018 [15]. In the same year approximately 10 million coconut trees with over 277 million nuts made up the Kenyan coconut industry of which 95\% are in the costal belt [37, 38]. The Coconut tree consists of roots, trunk, fonds or leaves, flowers and the nuts which are commercially exploitable. The roots can be used as dye stuff and for medicinal purposes but are often left in the field as dry stocks to be used for firewood; trunks are used for; fuel, making furniture, building huts and other physical structures, canoe building, coffin making and performing important cultural practices such as crafting of grave posts (kigango) [39]. Fonds, such as fallen, dry or used coconut leaves (kanja) are used mainly as roof thatching material (makuti) for both the local houses and exotic tourist hotels and also for stuffing pillows and mattresses, making brooms, weaving mats ( $m k e k a$ ) and fish traps, while sap from inflorescence (fruit bud), stem or root can be tapped to produce toddy (mnazi) which is fermented to produce an alcoholic drink (palm wine) $[40,39,38,41]$. The nuts are nutritious and are consumed at a tender stage (madafu) and at their mature stage in form of copra oils, copra cake, hence, the coconut trees are thus useful as cash crop due to their multi-purpose uses [42, 43]. The processing of coconut generates shell and husk as the main by-products and constitutes about $12 \%$ and $35 \%$ of the whole fruit by weight respectively [20]. Also, coconut cake meal is produced as a by-product of copra processing but due to its nutritional value, it is being used in confectionery [44].

For these 3 case studies of banana, Irish potatoes and coconut, a Material Flow Analysis in Kenya context was performed.

\section{Methodology 2.1 Material Flow Analysis}

MFA is a methodology that allows systematic analysis and quantification of flows and stocks of material or substances in a well-defined system in space and time. It analyses material sources, pathways and final destinations according to the mass balance principle i.e. the sum of all inputs equals the sum of all outputs, corrected with stock change if any. In this study, MFA is used to point out the potential for the valorization of three (3) selected types of biomass. Based on data availability, the MFA evaluate production quantities from the year 2018. Flow calculations were performed in Microsoft Excel, while the Sankey 5 pro software ( version e! Sankey pro 5.1.0) was used to develop the MFA flow diagrams. The subsequent section present essential information on system description, data used, and assumptions made.

\subsection{System boundary description}

The spatial border of Kenya defines the system boundary, implying that only waste generated within this spatial boundary will be considered in this study i.e., wastes related to import or export are excluded from this study. The temporal boundary was the year 2018. Furthermore, throughout the study, the term "waste" refers to a secondary product derived from agricultural production, supply, agro-industrial processing and consumption of the selected agro-products. This normally includes biomass that is inedible to humans, including food or by-products that are edible but are degraded beyond consumption or processing [45]. We follow waste generated over the production chain of the fruits, vegetables and nuts, including harvesting, processing, trading, consumption and final waste residual treatment. However, some potential wastes are not included in the study, for example, potato flowers, stem, branches and leaves dry out and drops before harvesting. Also, the banana rhizome is excluded from the study, since the new bud and suckers normally sprout from it [43]. Coconut roots, trunk 
and leaves are already extensively used thus are not considered as wastes in this study. To facilitate the usage of MFA, a generic scheme is developed (Fig. 1) that was used to assess the occurrence of the wastes. The functional unit is the total quantity of produce in 2018 , being $1447 \mathrm{kt}$ for bananas, $1870 \mathrm{kt}$ for potatoes and $105 \mathrm{kt}$ for coconut.

Figure 1 considers all parts of the banana plant except the rhizome. It also considers potato tubers and husked coconut and their associated processing wastes. All of the three case studies generate wastes at the farm gate (lines 2 and 3). However, those from coconut such as husks are separated by retting or decortication process (line 9 and 10) before they are finally processed and/or disposed of. Also, there are potato and banana rejects at the post-harvest (preparation, storage and distribution) (line 6), retailing (line 12) and consumption (line 13) stage. However, the quantity of banana rejected at post-harvest and retail stages is insignificant thus have not been considered, likewise to quantity of coconut used as seeds. Reused material waste are wastes that are generated after an initial use of a by-product or waste.

\subsection{Data source and assumptions}

In this study, mainly literature data was used. Production data for 2018 was sourced from FAOSTAT 2019 since it was the most recent source for which all required data on production were available for Kenya. Other available local data were used whenever possible. For the case of banana waste proportion and use, credible local data was not available, hence data was obtained from research conducted within the region of East and Central Africa and transposed to the Kenyan context. Waste was quantified in both dry and wet mass. The data on some potential key material resources in each by-product considered are given in Table 2.

Table 2

Production and waste quantity data sources

\begin{tabular}{|c|c|c|c|c|}
\hline Flow no. & Process in supply chain & Banana & Potato & Coconut \\
\hline 1 & Farm production (product) & [15] & [15] & [15] \\
\hline 2,3 & Farm production (waste) & {$[46,36]$, calculated from assumption ${ }^{a}$} & {$[47]$} & {$[20]$} \\
\hline 4 & Planting (Seeds) & n.a & [31] & n.a \\
\hline 5 & Preparation, storage and distribution (product) & {$[46,36]$} & {$[48,47]$} & {$[20]$} \\
\hline 6 & Preparation, storage and distribution (waste) & Negligibleb & [47] & n.a \\
\hline 7,8 & Factory processing, retailing (product) & [46] & [47] & [49] \\
\hline 9,10 & Retting process (waste) & n.a & n.a & [20] \\
\hline 11,12 & Factory processing and retailing (waste) & [27] & [47] & [49] \\
\hline 13 & House hold and restaurant consumer (waste) & Neglegible ${ }^{b}$ & {$[47]$} & [49] \\
\hline 14 & Banana food pulp, potato tuber for food and coconut based food & Calculatedi & Calculatedi & Calculated \\
\hline 15,16 & Consumed, secondary (waste) & {$[50]$} & {$[48]$} & [49] \\
\hline 17,18 & Discarded materials (waste) & Calculated ${ }^{i}$ & Calculated ${ }^{\mathrm{i}}$ & Calculated \\
\hline
\end{tabular}

In this work, quantity determinations were subjected to certain assumptions. The most important assumptions are:

i. All produce from each of the selected case studies strictly follow the supply chain as shown in Fig. 1.

ii. There is no significant difference in yield, morphology and phytochemical constituents among different varieties in each of the case studies, hence, an average value is adopted.

iii. Due to lack of data and for simplicity, imports and exports were not included.

\subsection{Recoverable bioresource classification}

The potential recovery of essential material from these wastes is discussed in the context of Kenyan need. A literature search was done on the concentrations of recoverable components and bioenergy potential. We classified recovery routes into four groups: high value compounds (e.g. phenolic materials), extractable (macro)compounds for use in feed and food (such as protein, starch and sugar), macrocompounds to be used as technical materials for industrial applications (such as fibers, cellulose and lignin), and bioenergy potential (such as biogas and bioethanol potential). The groups are as shown in Fig. 2.

\section{Result And Discussion}

\subsection{Quantity and occurrence}

Table 3 shows bananas, potatoes and coconut production and waste quantities, their current use and final disposal trends while Fig. 3, show their respective material flows. From Table 3 it can be deduced that, on fresh weight basis, $6007 \mathrm{kt}$ or $89.2 \%$ of total banana tree by-products is potential waste. Out of the 
total waste, pseudostem waste stream accounts for $72.2 \%$ of the wastes, followed by leaves (11.6\%), peels (10.6\%), stock (3.9\%), pulp (1.3\%) and male bud $(0.4 \%)$. As seen in Fig. 3 (a), a significant quantity of banana wastes (4359 kt) representing about $72.6 \%$ of the total wastes is discarded to nature (i.e. either disposed of in open landfills or water bodies, left to rot or burned without energy recovery). The rest of the wastes (1648 kt or about $27.4 \%$ ) are used as animal feed (649 kt) and as soil improver (999 kt)). However, soil improvement activities such as mulching are discouraged due to possibility of the propagation of diseases such as banana bacterial wilt [36].

In case of potato, for the total tuber produced, $1257 \mathrm{kt}(67.2 \%)$ is edible human food, $187 \mathrm{kt}(10 \%)$ is retained as planting seeds, while about $426 \mathrm{kt}(22.8 \%)$ are by-products in the form of peel (239 kt) and rejected tuber (187 kt). Further, the MFA analysis shown in Fig. 3 (b), depicts that just like in the case of banana, potato by-products are currently used as animal feed ( $136 \mathrm{kt}$ ) and for soil improvement ( $60 \mathrm{kt})$, representing $31.9 \%$ and $14.1 \%$ of the total by-products respectively, while $230 \mathrm{kt}$ representing about $54 \%$ of all potato wastes are discarded to nature.

For coconut, The Sankey diagram for coconut is shown in Fig. 3 (c). It shows that $49.5 \mathrm{kt}$ or $47.0 \%$ of the entire coconut produced is potential waste, consisting of $12.6 \mathrm{kt}$ shell (25.5\%), $25.8 \mathrm{kt}$ dust or pith (52.1\%), $11.1 \mathrm{kt}$ fiber (22.4\%). Also, from the diagram, only $459 \mathrm{t}(3.6 \%)$ of the shell is usable either for making charcoal ( $456 \mathrm{t}$ ) or artifacts ( $3 \mathrm{t})$, while about $12.2 \mathrm{kt}(96.4 \%)$ is discarded to nature. A combined $0.2 \%$ of fiber is used for making brooms (4t), ropes $(9$ t) and mats/mattresses (4 t), while (11,046 t) $99.8 \%$ of the fibers, especially short fibers, is discarded. So far, pith or dust or cocopeat is only used as soil improver or as plant growing medium at about 2,078 $\mathrm{t}(8.0 \%)$, while a significant proportion $23,736 \mathrm{t}(92.0 \%)$ is discarded in open land fill, thus, lost. In total, about $2,534 \mathrm{t}(5.2 \%)$ of coconut wastes are consumed while $46,966 \mathrm{t}(94.8 \%)$ is either discarded to nature whereas $20 \mathrm{t}$, is generated as a secondary waste source.

Comparably, on the basis of their respective total wastes, the highest percentage of materials discarded to open land fill occur in banana at $4359 \mathrm{kt}$ ( $94 \%$ ) followed by potato at $230 \mathrm{kt}(5.0 \%)$ and coconut at about $47 \mathrm{kt}(1.0 \%)$. However, it is remarkable that where the wastes are used, so far, it is limited to animal feed and soil improvement, next to some very specific applications such as ropes and toys. 
Table 3

Quantity of waste generated in Kenya and current destinations

\begin{tabular}{|c|c|c|c|c|c|c|c|c|c|c|c|c|}
\hline Biomass & $\begin{array}{l}\text { Nature of } \\
\text { Waste }_{\mathrm{FM}}\end{array}$ & $\begin{array}{l}\text { Waste/ } \\
\text { kt of } \\
\text { fruit } \\
\text { (kt/kt) }\end{array}$ & $\begin{array}{l}\text { Produce/waste } \\
\text { quantity }_{\mathrm{FM}}(\mathrm{kt})\end{array}$ & $\begin{array}{l}\text { Food } \\
\text { (kt) }\end{array}$ & $\begin{array}{l}\text { Feed } \\
(\mathrm{kt})\end{array}$ & $\begin{array}{l}\text { Compost } \\
\text { (kt) }\end{array}$ & $\begin{array}{l}\text { Mulch } \\
(\mathrm{kt})\end{array}$ & $\begin{array}{l}\text { Rope } \\
\text { making } \\
(\mathrm{kt})\end{array}$ & $\begin{array}{l}\text { Wrapping } \\
\text { (kt) }\end{array}$ & $\begin{array}{l}\text { Construction } \\
\text { (kt) }\end{array}$ & $\begin{array}{l}\text { Play/Toy } \\
\text { (kt) }\end{array}$ & $\begin{array}{l}\text { D } \\
(1\end{array}$ \\
\hline \multirow[t]{9}{*}{ Banana } & $\begin{array}{l}\text { Fruit } \\
\text { produced }\end{array}$ & 1.000 & 1447 & & & & & & & & & \\
\hline & Peels & $0.440^{\mathrm{a}}$ & 637 & & 185 & 449 & 0 & 0 & 0 & 0 & 0 & 3 \\
\hline & Pseudostem & $3.000^{\mathrm{a}}$ & 4341 & & 174 & 109 & 260 & 1281 & 0 & 0 & 1302 & 1 \\
\hline & Stock & $0.160^{\mathrm{a}}$ & 232 & & 10 & 119 & 0 & 1 & 0 & 0 & 39 & 6 \\
\hline & Leaves & $0.480^{\mathrm{a}}$ & 695 & & 257 & 0 & 0 & 0 & 351 & 3 & 31 & 5 \\
\hline & Pulp & $0.056^{\mathrm{a}}$ & 81 & 729 & 23 & 58 & 0 & 0 & 0 & 0 & 0 & 0 \\
\hline & Male bud & $0.016^{b}$ & 21 & 2 & 0 & 4 & 0 & 0 & 0 & 0 & 16 & 1 \\
\hline & Total waste & 4.152 & 6007 & 731 & 649 & 739 & 260 & 1282 & 351 & 3 & 1388 & 1 \\
\hline & $\begin{array}{l}\text { Tuber } \\
\text { produced }\end{array}$ & 1.000 & 1870 & & & & & & & & & \\
\hline \multirow[t]{4}{*}{ Potato } & Seed & $0.100^{c}$ & 187 & 187 & & & & & & & & \\
\hline & Peels & $0.128^{d}$ & 239 & & 76 & 34 & & & & & & 1 \\
\hline & Pulp & $0.100^{d}$ & 187 & 1257 & 60 & 26 & & & & & & 1 \\
\hline & Total waste & 0.328 & 613 & 1444 & 136 & 60 & & & & & & 2 \\
\hline \multirow[t]{7}{*}{ Coconut } & $\begin{array}{l}\text { Nature of } \\
\text { Waste }\end{array}$ & $\begin{array}{l}\text { Waste } \\
\text { (kt/kt) } \\
\text { of nut) }\end{array}$ & $\begin{array}{l}\text { Produce/waste } \\
\text { quantity }_{\mathrm{FM}}(\mathrm{kt})\end{array}$ & $\begin{array}{l}\text { Food } \\
\text { (kt) }\end{array}$ & Feed & $\begin{array}{l}\text { Charcoal } \\
\text { (kt) }\end{array}$ & $\begin{array}{l}\text { Artefact, } \\
\text { cups } \\
\text { (kaha) } \\
\text { (kt) }\end{array}$ & $\begin{array}{l}\text { Broom } \\
\text { (kt) }\end{array}$ & Rope (kt) & Mat (kt) & $\begin{array}{l}\text { Soil } \\
\text { conditioner } \\
\text { (kt) }\end{array}$ & $\stackrel{5}{(1}$ \\
\hline & $\begin{array}{l}\text { Coconut } \\
\text { produce }\end{array}$ & 1.000 & 105.362 & & & & & & & & & \\
\hline & Food $_{\mathrm{FM}}$ & $0.530^{\mathrm{e}}$ & 55.842 & 55.842 & & & & & & & & \\
\hline & Shell $_{\mathrm{DM}}$ & $0.120^{\mathrm{e}}$ & 12.643 & & & 0.456 & 0.003 & & & & & 1 \\
\hline & Fiber $_{D M}$ & $0.105^{\mathrm{e}}$ & 11.063 & & & & & 0.004 & 0.009 & 0.004 & & 1 \\
\hline & Dust $_{\mathrm{DM}}$ & $0.245^{\mathrm{e}}$ & 25.814 & & & & & & & & 2.078 & 2 \\
\hline & $\begin{array}{l}\text { Coconut } \\
\text { Total }\end{array}$ & 0.47 & 49520 & 55.842 & & 0.456 & 0.003 & 0.004 & 0.009 & 0.004 & 2.078 & 4 \\
\hline
\end{tabular}

${ }^{\mathrm{a}}$ Kabege et al. and Fernandez et al. [46, 51], ${ }^{\mathrm{b}}$ From assumption no. $2,{ }^{\mathrm{c}} \mathrm{GIZ}$ [31], ${ }^{\mathrm{d}}$ Musita et al. [34], ${ }^{\mathrm{e}}$ Verma et. al [20].

\subsection{Potential resource recovery analysis}

This section discusses the potential recoveries of the four classes of biomaterials (see supplementary data) and are summarized in Table 4.

\subsubsection{High value compounds}

From Table 4, it is shown that, flavonoid can mainly be obtained from banana wastes, with banana peels having the highest potential at 34.9 kt, followed by pseudostem (33.9 kt), leaves (3.8 kt), stock (1.5), and bud ( $0.1 \mathrm{kt})$, all totaling to $74.2 \mathrm{kt}$ flavonoids. Potato peels and mixed wastes have a potential to produce $0.4 \mathrm{kt}$ flavonoids while there is less potential for these components in coconut waste. For tannin extract, the highest quantity can be extracted from banana peel $(8.3 \mathrm{kt})$, coconut husk ( $1.8 \mathrm{kt})$, banana stock $(0.9 \mathrm{kt})$, coconut shell $(0.4 \mathrm{kt})$ and banana pulp $(0.2 \mathrm{kt})$. In total, banana waste has a total potential to produce $9.4 \mathrm{kt}$ tannin, coconut waste $(2.2 \mathrm{kt})$, while potato wastes have less potential.

If these resources are tapped e.g. as a natural dye, flavonoids from banana wastes ( $74.2 \mathrm{kt}$ ) can be used to dye about $608 \mathrm{million}^{2}$ of wool fabric (using dye to fabric ratio of $1: 5(\mathrm{w} / \mathrm{w})$ [52] assuming wool fabric weight $610 \mathrm{~g} / \mathrm{m}^{2}$ ), tannin from coconut ( $2.2 \mathrm{kt}$ ) would be used to tan about $220 \mathrm{kt}$ skin (at $1 \%$ (w/w) tanning process [53]).

\subsubsection{Extractable (macro)compounds for use in feed and food}

Banana waste has a high potential for refining extractable macro(compounds) that are usable as starting material for food and feed production processes (Table 4). In this category, starch is the main potential extractable material from banana waste streams (340.8 kt) with the highest quantities is recoverable from pseudostem (241.0 kt), followed by peel (71.2 kt), pulp (26.6 kt), leaves (1.2 kt) and stock (0.8 kt). From potato wastes streams, mixed waste and peels 
can generate $25.2 \mathrm{kt}$ and $11.0 \mathrm{kt}$ relatively while coconut has less potential. The potential for extractable sugar from pseudostem is $113.3 \mathrm{kt}$, leaves (6.5 kt), peel (2.1 kt), pulp and bud (1.4 kt) each. Each of the potato waste streams can produce $0.2 \mathrm{kt}$ each of the extractable sugar, while only coconut husk has a potential to produce $13.7 \mathrm{kt}$ of sugar. Banana pseudostem (31.0 kt), peel (13.4 kt), stock (5.9 kt), pulp (1.5 kt), leaves (1.5 kt) and bud (0.7 kt) have potential of producing protein.

Also, potato peel and mixed wastes streams each have a potential to produce $5.1 \mathrm{kt}$ of protein. In total, the most promising extractable feed materials from banana wastes in terms of masses are starch ( $340.8 \mathrm{kt})$, followed by sugar ( $124.7 \mathrm{kt})$ then protein $(54.0 \mathrm{kt})$. From potato waste, starch ( $36.2 \mathrm{kt})$ and protein $(10.2 \mathrm{kt})$ are the most significant recoverable (macro)compounds for use in feed and food, while from coconut waste, sugar (13.7 kt) from the husk seems most promising.

The starch from banana (340.8 kt) and potato ( $36.2 \mathrm{kt}$ ) wastes can size about 2,272.0 kt and $241.3 \mathrm{kt}$ cotton yarn (taking $15 \%$ of starch size per fiber (weight/weight) [54]) respectively; sugar from banana (124.7 kt) can produce 105 million liters ethanol, coconut (13.7 kt) can produce 11.5 million liters of ethanol (with the assumption that $1.6 \mathrm{~g}$ of sugar can produce $1.06 \mathrm{~g}$ ethanol [55]), while protein from banana $54.0 \mathrm{kt}$ can be used as a food supplement to produce $540 \mathrm{kt}$ spaghetti meal (at 10\% protein supplement in spaghetti flour [56])

\subsubsection{Macrocompounds used as technical materials for industrial applications}

Technical fiber can be recovered from banana pseudostem (476.1 kt), stock (9.8 kt), leaves ( $2.8 \mathrm{kt})$ and coconut husk (11.1 kt) as shown in Table 4 . For cellulose, the potential recoveries are banana pseudostem (1670.4 kt), leaves (247.3 kt), peel (23.3 kt), stock (15.3 kt) and bud (2.4 kt), potato mix (13.6 kt), potato peel $(0.7 \mathrm{kt})$, coconut husk $(19.2 \mathrm{kt})$, coconut shell $(8.5 \mathrm{kt})$

Table 4

Potential quantity of bioresource refinable from in banana waste streams

\begin{tabular}{|c|c|c|c|c|c|c|c|c|c|c|}
\hline \multirow[t]{2}{*}{ Biomass } & \multicolumn{2}{|c|}{$\begin{array}{l}\text { High value } \\
\text { compounds (kt) }\end{array}$} & \multicolumn{3}{|c|}{$\begin{array}{l}\text { Extractable } \\
\text { (macro)compounds for use in } \\
\text { feed and food (kt) }\end{array}$} & \multicolumn{3}{|c|}{$\begin{array}{l}\text { Macrocompounds used as technical materials for } \\
\text { industrial applications (kt) }\end{array}$} & \multicolumn{2}{|c|}{$\begin{array}{l}\text { Bioenergy potential } \\
\text { (GWh) }\end{array}$} \\
\hline & Flavonoid & Tannin & Starch & Protein & Sugar & Fiber & Cellulose & Lignin & $\begin{array}{l}\text { Biogas* } \\
\text { (GWh) }\end{array}$ & $\begin{array}{l}\text { Bioethanol } \\
\text { (GWh) }\end{array}$ \\
\hline $\begin{array}{l}\text { Banana } \\
\text { Peel }\end{array}$ & 34.9 & 8.3 & 71.2 & 13.4 & 2.1 & limited & 23.3 & 24.9 & 305.4 & 34.4 \\
\hline Pseudostem & 33.9 & limited & 241.0 & 31.0 & 113.3 & 476.1 & 1670.4 & 250.5 & 981.7 & 189.7 \\
\hline Stock & 1.5 & 0.9 & 0.8 & 5.9 & limited & 9.8 & 15.3 & 9.2 & 70.7 & 26.8 \\
\hline Leaves & 3.8 & limited & 1.2 & 1.5 & 6.5 & 2.8 & 247.3 & 73.5 & 91.6 & 28.8 \\
\hline $\begin{array}{l}\text { Banana } \\
\text { pulp }\end{array}$ & 0.1 & 0.2 & 26.6 & 1.5 & 1.4 & limited & limited & limited & 69.0 & 19.2 \\
\hline Male bud & limited & limited & limited & 0.7 & 1.4 & limited & 2.4 & 0.6 & 6.8 & 0.7 \\
\hline Potato peel & 0.4 & limited & 11.0 & 5.1 & 0.2 & limited & 0.7 & 9.6 & 79.2 & 11.6 \\
\hline Potato mix & limited & limited & 25.2 & 5.1 & 0.2 & limited & 13.6 & 2.8 & 77.4 & 34.4 \\
\hline $\begin{array}{l}\text { Coconut } \\
\text { shell }\end{array}$ & limited & 0.4 & limited & limited & limited & limited & 8.5 & 3.9 & 56.0 & limited \\
\hline $\begin{array}{l}\text { Coconut } \\
\text { husk }\end{array}$ & limited & 1.8 & limited & limited & 13.7 & 11.1 & 19.2 & 15.5 & 19.2 & 10.3 \\
\hline
\end{tabular}

Limited - less than $0.1 \mathrm{kt}$, *calculated from $6.5 \mathrm{KWh}$ per $\mathrm{m}^{3}$ biogas [57], ${ }^{\star \star}$ Calculated from the lower heating value (LHV) of $1 \mathrm{~kg}$ of EtOH (7.47 KWh/kg [58]) 
Table 5

Summary of the potential of biomaterial recovery from bio-wastes

\begin{tabular}{|c|c|c|c|c|c|c|c|c|}
\hline Waste Parts & $\begin{array}{l}\text { Moisture } \\
\text { content }\end{array}$ & $\begin{array}{l}\text { Dry } \\
\text { matter } \\
\text { (\%) }\end{array}$ & $\begin{array}{l}\text { Quantity }_{\mathrm{FM}} \\
\text { (kt) }\end{array}$ & $\begin{array}{l}\text { Quantity } \\
(\mathrm{t})\end{array}$ & Occurance & Main Current destination & $\begin{array}{l}\text { Potential future } \\
\text { destination }\end{array}$ & $\begin{array}{l}\text { Overal } \\
\text { potential }\end{array}$ \\
\hline $\begin{array}{l}\text { Banana } \\
\text { Peels }\end{array}$ & $83.3^{\mathrm{a}}$ & 28.0 & 637 & 178 & $\begin{array}{l}\text { Mainly } \\
\text { dispersed }\end{array}$ & Compost, feeding & $\begin{array}{l}\text { Flavonoid, starch, lignin, } \\
\text { biogas }\end{array}$ & Medium \\
\hline Pseudostem & $90.0^{\mathrm{b}}$ & 18.6 & 4341 & 807 & Central & $\begin{array}{l}\text { Play, rope, discarded } \\
\text { (rotting/burned) }\end{array}$ & $\begin{array}{l}\text { Flavonoid, starch, } \\
\text { cellulose, biogas }\end{array}$ & High \\
\hline Stock & $90.5^{a}$ & 49.0 & 232 & 49 & Central & Compost, discarded, play & $\begin{array}{l}\text { Flavonoid, protein, } \\
\text { cellulose, biogas }\end{array}$ & High \\
\hline Leaves & $80.0^{\mathrm{b}}$ & 77.0 & 695 & 77 & Central & Wrapping, feeding & $\begin{array}{l}\text { Flavonoid, Sugar, } \\
\text { cellulose, biogas }\end{array}$ & High \\
\hline $\begin{array}{l}\text { Banana } \\
\text { Pulp }\end{array}$ & $70.1^{a}$ & 41.0 & 81 & 33 & $\begin{array}{l}\text { Mainly } \\
\text { dispersed }\end{array}$ & Compost, feeding & Tannin, starch, biogas & Medium \\
\hline Male bud & $87.5^{\mathrm{b}}$ & 41.0 & 23 & 5 & Central & Play & Sugar, cellulose, biogas & High \\
\hline Potato peel & $86.5^{c}$ & 23.0 & 239 & 48 & $\begin{array}{l}\text { Mainly } \\
\text { dispersed }\end{array}$ & Discarded, feed & $\begin{array}{l}\text { Flavonoid, starch, lignin, } \\
\text { biogas }\end{array}$ & Medium \\
\hline Potato mix & $76.8^{c}$ & 20.2 & 187 & 55 & $\begin{array}{l}\text { Mainly } \\
\text { dispersed }\end{array}$ & Discarded, feed & Starch, cellulose, biogas & Medium \\
\hline $\begin{array}{l}\text { Coconut } \\
\text { shell }\end{array}$ & $20^{d}$ & n.a & 13 & 13 & $\begin{array}{l}\text { Mainly } \\
\text { dispersed }\end{array}$ & $\begin{array}{l}\text { Discarded, soil } \\
\text { improvement }\end{array}$ & $\begin{array}{l}\text { Tannin, cellulose, } \\
\text { biogas }\end{array}$ & Medium \\
\hline $\begin{array}{l}\text { Coconut } \\
\text { husk }\end{array}$ & $32^{d}$ & n.a & 37 & 37 & Central & $\begin{array}{l}\text { Discarded, soil } \\
\text { improvement }\end{array}$ & $\begin{array}{l}\text { Tannin, sugar, cellulose, } \\
\text { biogas }\end{array}$ & High \\
\hline
\end{tabular}

For lignin, the highest potential sources lies in pseudostem (250.5 kt), banana leaves (73.5 kt), banana peel (24.9 kt), coconut husk (15.5 kt), potato peel (9.6 $\mathrm{kt})$, banana stock (9.2), coconut shell (3.9 kt), potato mix ( $2.8 \mathrm{kt})$ and bud $(0.6 \mathrm{kt})$. Thus the total potential recovery for macrocompounds used as technical materials for industrial applications is: fiber from banana (488.7 kt) and coconut (11.1 kt); cellulose from banana (1958.7 kt), potato (14.3 kt) and coconut (27.7 kt); while from lignin from banana (358.7 kt), potato (12.4 kt) and coconut (19.4 kt)

The fiber from banana (488.7 kt) is capable of producing $1221.8 \mathrm{kt}$ plain-woven banana fiber/polyester blend fabric or 2.4 million $\mathrm{m}^{3}$ of fabric ( assuming $40 \%$ banana fiber in hybrid polyester blend [63], banana fiber density $1200 \mathrm{~kg} / \mathrm{m}^{3}$ and polyester density of $60 \mathrm{~kg} / \mathrm{m}^{3}$, thus the fiber blend density is $516 \mathrm{~kg} / \mathrm{m}^{2}$ ), from coconut (11.1 kt), $27.8 \mathrm{kt}$ fabric or about $54,000 \mathrm{~m}^{3}$ fiber can be produced (assuming same values as for banana/polyester blend), the cellulose from banana ( $1670.4 \mathrm{kt}$ ) is capable of producing $19,815 \mathrm{kt}$ of paper hand sheet (assuming $84.3 \%$ of cellulose in paper pulp (450 SR) [64]), from potato (14.3 kt), $16.9 \mathrm{kt}$ can be produced, while coconut $(27.7 \mathrm{kt}$ ) can produce $32.9 \mathrm{kt}$. Lignin from banana ( $358.7 \mathrm{kt})$ is capable of producing $377.6 \mathrm{kt}$ composite polymer blend material ( taking cases of $95 \%$ lignin, $5 \%$ poly(ethylene) oxide [65]), $13.1 \mathrm{kt}$ from potato (12.4 kt), while coconut (20.4 kt) has a potential to produce $21.5 \mathrm{kt}$.

\subsubsection{Bioenergy potential}

Related to biogas production, from Table 4, banana waste streams have potential to give 173.6 (981.7 GWh), 54.0 (305.4 GWh), 16.2 (91.6 GWh), 12.5 (70.7 $\mathrm{GWh}), 12.2$ (69.0 GWh), 1.2 (6.8 GWh) million $\mathrm{m}^{3}$ biogas (energy equivalent) from pseudostem, peel, leaves, stock, pulp and buds respectively, totaling to 269.7 million $\mathrm{m}^{3}$ or $1525.2 \mathrm{GWh}$ biogas energy potential (energy conversion is $6.5 \mathrm{KWh}$ per $\mathrm{m}^{3}$ biogas and considering transportation and biodigester selfconsumption of about $13 \%[57,62])$. Bioethanol energy can potentially be produced from pseudostem 27.6 (189.7 GWh), peels 5.0 ( $34.4 \mathrm{GWh}$ ), leaves 4.2 (28.8 GWh), stock $3.9(26.8 \mathrm{GWh})$, pulp $2.8(19.2 \mathrm{GWh})$ and bud $0.1(0.7 \mathrm{GWh})$, with a potential total of $43.6 \mathrm{kt}$ or $299.6 \mathrm{GWh}$ (Calculated from the lower heating value (LHV) of $1 \mathrm{~kg}$ of EtOH generating $7.47 \mathrm{KWh}$ energy and transportation energy consumption of $8 \%$ [58, 62]). Potato peel and mix waste have a potential to produce $13.7(77.4 \mathrm{GWh})$ and $14.0(79.2 \mathrm{GWh})$ million $\mathrm{m}^{3}$ biogas, and about $5 \mathrm{kt}(34.4 \mathrm{GWh})$ and $1.7 \mathrm{kt}(11.6 \mathrm{GWh})$ potential bioethanol respectively, totaling to about 6.7 million $\mathrm{m}^{3}(156.6 \mathrm{GWh})$ biogas and $6.7 \mathrm{kt}(46.0 \mathrm{GWh})$ bioethanol. While for coconut wastes, the husk and shell are capable of giving about $9.9(56 \mathrm{GWh})$ and $3.4(19.2 \mathrm{GWh})$ million $\mathrm{m}^{3}$ biogas respectively totaling to 13.3 million $\mathrm{m}^{3}(75.2 \mathrm{GWh})$ biogas, with only the coconut husk being able to give $1.5 \mathrm{kt}(10.3 \mathrm{GWh})$ bioethanol

The biogas energy realizable from banana waste ( $1525.2 \mathrm{GWh}$ ) (which can be converted $40 \%$ to electricity and $50 \%$ to heat [66]) is capable of producing 610.1 GWh electricity/year and $762.6 \mathrm{GWh}$ heat/year to support (at an average consumption of $620 \mathrm{KWh}$ electricity and $600 \mathrm{KWh}$ heat per year per house hold) about 984,032 and 1.3 million households per year respectively. Bioethanol energy from banana waste has a potential to generate $299.6 \mathrm{GWh} / \mathrm{year}$ of heat energy/year capable of supporting about 499,333 households. Biogas from potato ( $156.6 \mathrm{GWh}$ ) has a potential to generate $62.6 \mathrm{GWh}$ electricity and $78.3 \mathrm{GWh}$ heat per year capable of supporting about 100,967 and 130,500 households per year respectively while 46 GWh potential heat energy from bioethanol can support 76,666 households. Potential biogas energy from coconut waste $(75.2 \mathrm{GWh})$ having the potential to generate 30.1 and $37.6 \mathrm{GWh}$ of electricity and heat/year capable of supporting 48,548 and 62,666 households per year while bioethanol energy ( $1.5 \mathrm{kt}$ or $10.3 \mathrm{GWh}$ ) can support 17,166 households. Overall, production biogas as a source of energy has more potential than bioethanol production. 


\subsection{The overall Potential of waste valorization}

Figure 1, given in Sect. 2.1, illustrate the supply chains for banana, potato and coconut produce and the corresponding wastes generated at each stage. From Fig. 1, it is evident that wastes generated at the farm gate, supply line 2 and 3 such as pseudostem, leaves, buds, damaged tubers and coconut husks are centrally generated in the farms. Similarly, wastes given by supply line 6 and 11 such as stock, and rejects and those from factory processing such as peels, rejects and shells are also centrally generated thus, are easier to collect. Conversely, the by-products that are generated at the last two stages of the supply chain (line 12 and line 13) such as wastes from retailers, household and restaurant processing are more widely dispersed. For example, hawking or street vending, a common method of retailing in Kenya, typically involves vendors constantly moving from one street to the other with their merchandise in search of buyers [67]. This method of selling covers a wide random area, without a strategy of waste collection, consequently spreads the generated wastes over a winder area. Nevertheless, for centralized customers and restaurants, with the introduction of waste segregation and collection arrangements, a significant quantity ( at least $50 \%$ ) of peels and rejects can be recovered. Thus, in general, all waste streams from bananas, potatoes and coconut have the potential for valorization except those generated at retailing, household and restaurant processing stage, which might better be mixed with other organic wastes towards composting or digestion (Table 5).

Considering the waste biomass availability, occurrences and current destination as summarized in Table 5 , it is evident that all waste streams have high to medium potential for biorefining of various indicated biomaterials. However, an effort to recover the biomaterial should take into account the moisture content. For example, nut wastes have low moisture content, thus, are durable and can be stored for a longer period before use, while all other wastes have high moisture content hence are susceptible to decay, therefore, they might need drying before a delayed use or should be used within few days after harvesting, which might pose storing challenge.

E-supplementary data of this work can be found in online version of the paper.

\section{Conclusion}

Bio-waste generation and analysis in Kenya was mapped for banana, potatoes and coconut Large quantities of waste are generated over the value chain (such as banana $(6007 \mathrm{kt})$, potato $(426 \mathrm{kt}$ ) and coconut $(49.5 \mathrm{kt})$ ) with the bulk being generated centrally and thus relatively feasible for collection and biorefinery. All waste streams can be valorized via different valorization routes to produce different bioresource. From the three selected biomass types, we can valorize flavonoids ( $88.3 \mathrm{kt})$, starch (377 kt), cellulose (2000.7 kt) and biogas (1757.0 GWh), offering a huge potential for the Kenyan bioeconomy. Further, the results of the study can inform policy making on waste management systems.

\section{Declarations}

\section{Declaration of Competing Interest}

The authors declare that they have no known competing financial interests or personal relationships that could have appeared to influence the work reported in this paper.

\section{Acknowledgements}

The authors hereby acknowledge that this research work has been conducted within the framework of the TEAM project 'Towards a more integrated management of organic waste in Kenya; the production of natural dyes from fruit and vegetable waste', Project no. KE2018TEA464A103 with financial support from the VLIR-UOS, Belgium.

\section{References}

1. Government of Kenya: National sustainable waste management policy. In: forestry, Min. of Environ. and Forestry (ed.), vol. II, Revised draft. GoK, Republic of Kenya, (2019)

2. Kenya National Bureau of Statistics: 2019 Kenya population and housing census. In: statistics, K.N.B.o. (ed.), vol. II. (2019)

3. Agency, U.S.E.a.P.: advancing resource efficiency in the supply chain - observations and opportunities for action. In: U.S. EPA's reflections on the U.S.hosted workshop on the use of Life Cycle concepts in supply chain management to achieve resource efficiency, March 22-23, 2016. (2016)

4. Matopoulos, A., Barros, A., Van der Vorst, J.: Resource-efficient supply chains: A research framework, literature review and research agenda. Sup. Chain Manag.20, 218-236 (2015). doi:10.1108/SCM-03-2014-0090

5. Corrado, S., Sala, S.: Bio-economy contribution to circular economy. In: Benetto, E., Gericke, K., Guiton, M. (eds.) Designing sustainable technologies, products and policies: From science to innovation. pp. 49-59. Spring. Inter. Pub., Cham (2018)

6. UNDP: Nationally appropriate mitigation action on a circular economy solid waste management approach for urban areas in kenya. In: Wilde, G. (ed.). Min. of Environ. Nat. Res., Nairobi (2016)

7. UNEP: Green economy sector study on agriculture in Kenya. p. 34. (2015)

8. Blottnitz, A.K.A.H.V.: Solid waste management in Nairobi: A situation analysis. In: Group, E.P.S.E. (ed.). Uni. of Cape Town, (2010)

9. Gituma, K., Waswa, F.: Enhancing benefits from biomass wastes within small-medium scale coffee processing factories in Kiambu county, Kenya. Afri. J. Envi. Sci. and Tech.11, 198-206 (2017). doi:10.5897/AJEST2016.2243 
10. Caldeira, C., De Laurentiis, V., Corrado, S., van Holsteijn, F., Sala, S.: Quantification of food waste per product group along the food supply chain in the European Union: a mass flow analysis. Res., Conser. and Rec.149, 479-488 (2019). doi:https://doi.org/10.1016/j.resconrec.2019.06.011

11. Turner, D.A., Williams, I.D., Kemp, S.: Combined material flow analysis and life cycle assessment as a support tool for solid waste management decision making. J. Clean. Prod.129, 234-248 (2016). doi:https://doi.org/10.1016/j.jclepro.2016.04.077

12. Eckelman, M.J., Chertow, M.R.: Using Material Flow Analysis to illuminate long-term waste management solutions in Oahu, Hawaii. J. Indu. Ecol.13(5), 758-774 (2009). doi:10.1111/j.1530-9290.2009.00159.x

13. Pirani, S.I., Arafat, H.A.: Reduction of food waste generation in the hospitality industry. J. of Clean. Prod.132, 129-145 (2016). doi:https://doi.org/10.1016/j.jclepro.2015.07.146

14. Waweru, S.: Kilimo Biashara: Covid-19 yaharibu faida ya wakulima wa machungwa. In: Taifa leo. Nirobi, Kenya, (2020)

15. FAOSTAT: Food and Agricutural Organization data. (2019)

16. Elanthikkal, S., Gopalakrishnapanicker, U., Varghese, S., Guthrie, J.T.: Cellulose microfibres produced from banana plant wastes: Isolation and characterization. Carbo. Poly.80(3), 852-859 (2010). doi:https://doi.org/10.1016/j.carbpol.2009.12.043

17. De Laurentiis, V., Corrado, S., Sala, S.: Quantifying household waste of fresh fruit and vegetables in the EU. Waste Manag.77, 238-251 (2018). doi:https://doi.org/10.1016/j.wasman.2018.04.001

18. Joshi, V., Kumar, A., Kumar, V.: Antimicrobial, antioxidant and phyto-chemicals from fruit and vegetable wastes: A review. Int. J. Food and Ferment. Technol.2, 123-136 (2012).

19. Ubalua, A.: Cassava wastes: Treatment options and value addition alternatives. African J. Biotechnol. (ISSN: 1684-5315) Vol 6 Num 18 6 (2007). doi:10.5897/AJB2007.000-2319

20. Verma, D., Gope, P.C.: 10 - The use of coir/coconut fibers as reinforcements in composites. In: Faruk, O., Sain, M. (eds.) Biofiber reinforcements in composite materials. pp. 285-319. Woodhead Publishing, (2015)

21. Braga, N., Rodrigues, F., P.P. Oliveira, M.B.: Castanea sativa by-products: a review on added value and sustainable application. Natural Product Research 29(1), 1-18 (2015). doi:10.1080/14786419.2014.955488

22. Rivas, S., Moure, A., Parajó, J.C.: Pretreatment of hazelnut shells as a key strategy for the solubilization and valorization of hemicelluloses into bioactive compounds. Agronomy 10(6) (2020). doi:10.3390/agronomy10060760

23. Padam, B.S., Tin, H.S., Chye, F.Y., Abdullah, M.I.: Banana by-products: an under-utilized renewable food biomass with great potential. J. Food Sci. Technol.51(12), 3527-3545 (2014). doi:10.1007/s13197-012-0861-2

24. Tock, J.Y., Lai, C.L., Lee, K.T., Tan, K.T., Bhatia, S.: Banana biomass as potential renewable energy resource: A Malaysian case study. Renew. and Sustain. Energy Reviews 14(2), 798-805 (2010). doi:https://doi.org/10.1016/j.rser.2009.10.010

25. Shah, M., Reddy, G., Banerjee, R., Babu, P., Kothari, I.L.: Microbial degradation of banana waste under solid state bioprocessing using two lignocellulolytic fungi (Phylosticta spp. MPS-001 and Aspergillus spp. MPS-002). Pro. Biochem.40, 445-451 (2005). doi:10.1016/j.procbio.2004.01.020

26. Kenya National Bureu of Statistics: Horticulture validated report 2016 - 2017. In: Africulture and food authority, H.C.D. (ed.). Nairobi, Kenya, (2018)

27. Food and Agricultural Organization of the United Nations: Food loss assessments: Causes and solutions. Rome, (2014)

28. Laititi, M.S.: Potato market survey in Kenya: An agricultural product value chain approach. Intern. J. Bus. and Manag. Review 2(6), 59 - 87 (2014).

29. Kenya, N.P.C.o.: Potato Production Handbook: A guidline for farmers and trainers. (2018)

30. Wachira, K., Gladys, M., Meshack, R., Ochere, E.: Potato market survey report. In: National Potato Council of Kenya. USAID-KAVES, Nairobi, Kenya, (2014)

31. GIZ: Modernization options for the potato value chain in Kenya and Nigeria. In: Kenya, D.o.G.I.A.C.I. (ed.). GIZ, Bonn, Germany, (2016)

32. Maina, M., Marion, G., Patrick, O., Nancy, N.A..A.., Abed, K., Simon, K., Jackson, M., Dinah, B.: The national potato stratergy 2016 - 2020 . In: Ministry of Agriculture, L.A.F. (ed.). GoK, Nairobi, Kenya, (2015)

33. Pavlista, A., D.: EC95-1249 potato production stages: Scheduling key practices In: Lincoln, U.o.N.-L.D.U.o.N.-. (ed.) Historical Materials from University of Nebraska-Lincoln Extension p. 1584. (1995)

34. Musita, C., Okoth, M., Abong, G.: Postharvest handling practices and perception of potato safety among potato traders in Nairobi, Kenya. Intern. J. Food Sci.2019, 1-8 (2019). doi:10.1155/2019/2342619

35. GIZ: Challenge: Food not waste - Developing innovative business solutions for the food waste problem in Kenya. In. Federal ministry of economic cooporation and development, Berlin, Germany, (2016)

36. Gumisiriza, R., Hawumba, J., Simon, A., Balyeidhusa, P., Okure, M., Hensel, O.: Processing of East African highland green bananas: Waste generation and characterization as a potential feedstock for biogas production in Uganda. 215-236 (2019).

37. Nuts and oil crops directorate: Nuts and oil statistical repot 2018/2019. In. Agriculture and food authority (2020)

38. Kenya Coconut Development Authority: National coconut survey 2013 final report. (2013)

39. Abuya, W.: What is in a coconut? An ethnoecological analysis of mining, social displacement, vulnerability, and development in rural Kenya. African Stud. Quart.14, 1-21 (2013).

40. Mwachiro, E., Kenyatta, J.: Factors affecting the coconut industry from benefitting the indigenous communities of Kilifi district, Kenya. 2011

41. Kdere, T.T.: Baseline Survey, Biochemical, Microbial, and Technological Studies on “Mnazi'. JKUAT (2009)

42. 42.Agricultural and Food Authority: Annual market research In: Masira, I. (ed.). Nuts and Oil Crops Directorate Mombasa, Kenya, (2016)

43. Kadere, T., Oniango, R., Kutima, P., Njoroge, S.: Production, marketing and economic importance of mnazi and other coconut-based products in Kenya. (2009).

Page $12 / 15$ 
44. Kaur, K., Chhikara, N., Sharma, P., Garg, M.K., Panghal, A.: Coconut meal: Nutraceutical importance and food industry application. Foods and Raw Mat.7, 419-427 (2019). doi:10.21603/2308-4057-2019-2-419-427

45. Alexander, P., Brown, C., Arneth, A., Finnigan, J., Moran, D., Rounsevell, M.: Losses, inefficiencies and waste in the global food system. Agric. Systems 153, 190-200 (2017). doi:10.1016/j.agsy.2017.01.014

46. Kabenge, I., Omulo, G., Banadda, N., Seay, J., Zziwa, A., Kiggundu, N.: Characterization of banana peels wastes as potential slow pyrolysis feedstock. J. Sustain. Devel.11, 14 (2018). doi:10.5539/jsd.v11n2p14

47. Kaguongo, W., Maingi, G., Giencke, S.: Post-harvest losses in potato value chains in Kenya: Analysis and recommendations for reduction strategies. (2014)

48. Mugo, S.W.: Assessment of solid waste management at Wakulima Market in Nairobi city, Kenya. University of Nairobi (2019)

49. Alpex: National coconut survey 2013 final report. In. Kenya Coconut Development Authority, (2014)

50. Kamira, M., Katungu, M., Ntamwira, Bigabwa, J, Blome, G., Ocimati, W.: Household uses of the banana plant in eastern Democratic Republic of Congo. Journal of Applied Biosciences 95 (2015). doi:10.4314/jab.v95i1.1

51. Fernandes, E., Marangoni, C., Souza, O., Sellin, N.: Thermochemical characterization of banana leaves as a potential energy source. Energy Convers. Manag.75, 603-608 (2013). doi:10.1016/j.enconman.2013.08.008

52. Guinot, P., Gargadennec, A., Valette, G., Fruchier, A., Andary, C.: Primary flavonoids in marigold dye: extraction, structure and involvement in the dyeing process. Phytochem Anal.19(1), 46-51 (2008). doi:10.1002/pca.1014

53. Pinto, P.C.R., Sousa, G., Crispim, F., Silvestre, A.J.D., Neto, C.P.: Eucalyptus globulus bark as source of tannin extracts for application in leather industry. ACS Sustain. Chem. \& Eng.1(8), 950-955 (2013). doi:10.1021/sc400037h

54. Djordjevic, S., Kovacevic, S., Djordjevic, D., Konstantinovic, S.: Sizing process of cotton yarn by size from a copolymer of methacrylic acid and hydrolyzed potato starch. Text. Res. J.89(17), 3457-3465 (2018). doi:10.1177/0040517518813628

55. Ergun, M., Ferda Mutlu, S.: Application of a statistical technique to the production of ethanol from sugar beet molasses by Saccharomyces cerevisiae. Biores. Technol.73(3), 251-255 (2000). doi:https://doi.org/10.1016/S0960-8524(99)00140-6

56. Alzuwaid, N.T., Pleming, D., Fellows, C.M., Sissons, M.: Fortification of durum wheat spaghetti and common wheat bread with wheat bran protein concentrate-impacts on nutrition and technological properties. Food Chem.334, 127497 (2021). doi:https://doi.org/10.1016/j.foodchem.2020.127497

57. Pongrácz, E., Tomperi, J.: Energy potential of biodegradable wastes in Kolari. Pollack Periodica, Intern. J. Eng. and Info. Sci.9, 5-15 (2014). doi:10.1556/Pollack.9.2014.S.1

58. Wobiwo, F., Chaturvedi, T., Boda, M., Fokou, E., Emaga, T., Cybulska, I., Deleu, M., Gerin, P., Thomsen, M.: Bioethanol potential of raw and hydrothermally pretreated banana bulbs biomass in simultaneous saccharification and fermentation process with Saccharomyces cerevisiae. Biom. Conver. and Bioref. (2019). doi:10.1007/s13399-018-00367-0

59. Salyeem, E., E., Mshandete, A., Kivaisi, A., K.: Biovalorization of banana waste: auditing and improvement of bio-methane production by fungal pretreatment. J. Chem. Bio. Phys. Sci. 4, 818-833 (2014).

60. Chintagunta, A.D., Jacob, S., Banerjee, R.: Integrated bioethanol and biomanure production from potato waste. Waste Manag 49, $320-325$ (2016). doi:10.1016/j.wasman.2015.08.010

61. Yaw Obeng, G., Yeboah, D., Opoku, R., Sekyere, C., Adjei, E.A., Mensah, E.: Coconut wastes as bioresource for sustainable energy: Quantifying wastes, calorific values and emissions in Ghana. Energies 13, 2178 (2020). doi:10.3390/en13092178

62. Wobiwo, F., Emaga, T., Fokou, E., Boda, M., Gillet, S., Deleu, M., Richel, A., Gerin, P.: Comparative biochemical methane potential of some varieties of residual banana biomass and renewable energy potential. Biom. Conver. and Bioref.7 (2016). doi:10.1007/s13399-016-0222-x

63. Alavudeen, A., Rajini, N., Karthikeyan, S., Thiruchitrambalam, M., Venkateshwaren, N.: Mechanical properties of banana/kenaf fiber-reinforced hybrid polyester composites: Effect of woven fabric and random orientation. Materials \& Design (1980-2015) 66, 246-257 (2015).

doi:https://doi.org/10.1016/j.matdes.2014.10.067

64. Saikia, C., Goswami, T., Ali, F.: Evaluation of pulp and paper making characteristics of certain fast growing plants. Wood Sci. and Technol.31, 467-475 (2004).

65. Kadla, J.F., Kubo, S.: Miscibility and hydrogen bonding in blends of poly(ethylene oxide) and kraft lignin. Macromolecules 36(20), 7803-7811 (2003). doi:10.1021/ma0348371

66. Pöschl, M., Ward, S., Owende, P.: Evaluation of energy efficiency of various biogas production and utilization pathways. Applied Energy 87(11), 3305-3321 (2010). doi:https://doi.org/10.1016/j.apenergy.2010.05.011

67. Mitullah, W.: Street vending in African cities: A synthesis of empirical finding from Kenya, Cote D'Ivoire, Ghana, Zimbabwe, Uganda and South Africa. (2003).

\section{Figures}




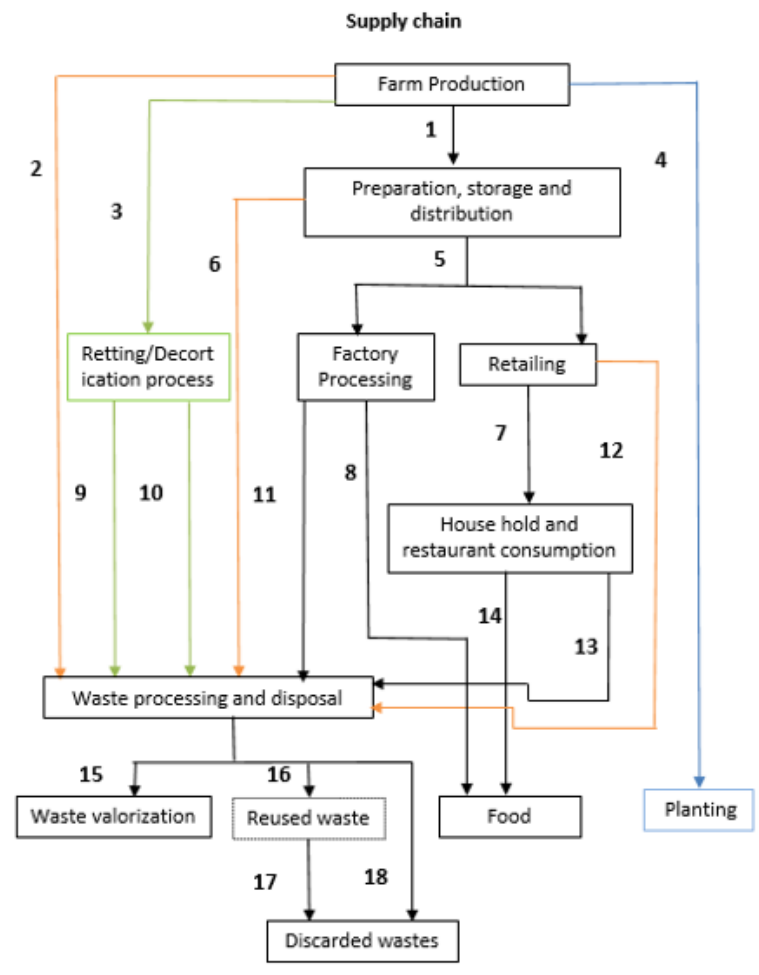

\begin{tabular}{|c|c|c|c|}
\hline & Banana & Potato & Coconut \\
\hline 1 & fruit & tuber & $\begin{array}{l}\text { dehusked nut, } \\
\text { madafu }\end{array}$ \\
\hline 2 & $\begin{array}{l}\text { leaves, pseudo- } \\
\text { stem, bud }\end{array}$ & damaged tuber & n.a \\
\hline 3 & n.a & n.a & husk \\
\hline 4 & n.a & seed & negligible \\
\hline 5 & fruit & tuber & dehusked nut \\
\hline 6 & stock & reject & n.a \\
\hline 7 & fruit & tuber & dehusked nut \\
\hline 8 & pulp & pulp & $\begin{array}{l}\text { oil, water, } \\
\text { meat }\end{array}$ \\
\hline 9 & n.a & n.a & fiber \\
\hline 10 & n.a & n.a & dust \\
\hline 11 & peel & peel & shell \\
\hline 12 & n.a & reject & n.a \\
\hline 13 & peel & peel, reject & shell \\
\hline 14 & food pulp & food tuber & $\begin{array}{l}\text { copra, oil, } \\
\text { water, cake }\end{array}$ \\
\hline 15 & $\begin{array}{l}\text { feed, compost, } \\
\text { mulch, others }\end{array}$ & $\begin{array}{l}\text { feed, compost, } \\
\text { mulch }\end{array}$ & $\begin{array}{c}\text { Soil improver, } \\
\text { charcoal }\end{array}$ \\
\hline 16 & $\begin{array}{l}\text { rope, wrapping, } \\
\text { construction, } \\
\text { play item }\end{array}$ & n.a & $\begin{array}{c}\text { broom, } \\
\text { mat/matress } \\
\text { artifact }\end{array}$ \\
\hline 17,18 & $\begin{array}{c}\text { land/water fill, } \\
\text { left to rot, } \\
\text { burned }\end{array}$ & $\begin{array}{c}\text { land/water fill, } \\
\text { left to rot, } \\
\text { burned }\end{array}$ & $\begin{array}{c}\text { land/water fill, } \\
\text { left to rot, } \\
\text { burned }\end{array}$ \\
\hline
\end{tabular}

_ Banana, potato and coconut ___ Banana and potato

Coconut

Banana and coconut

n.a: not available

\section{Figure 1}

Kenyan agricultural production supply chain

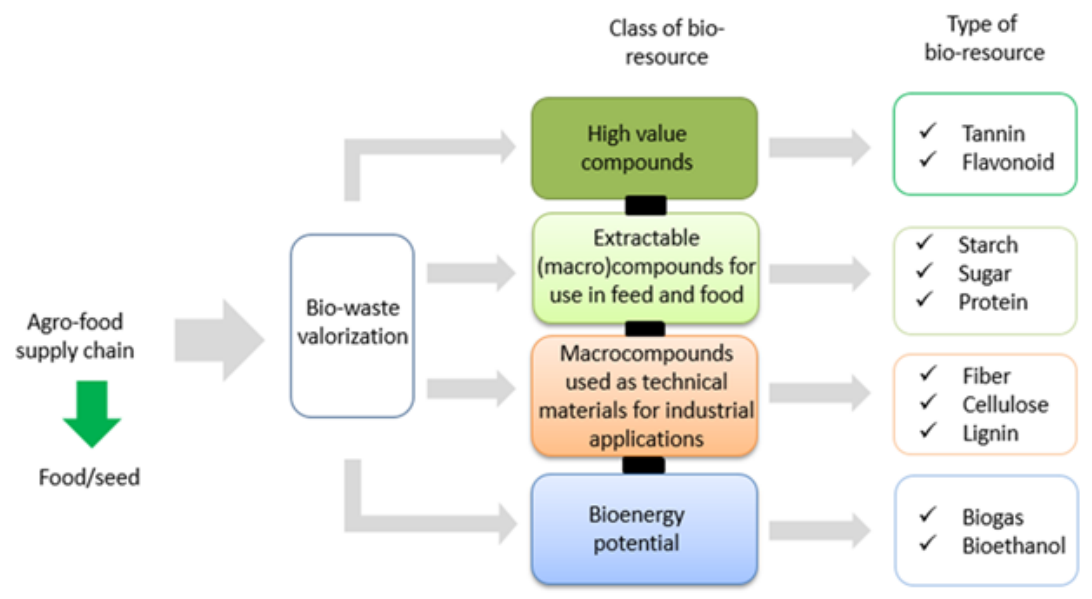

\section{Figure 2}

Classification of recoverable biomaterial resource 


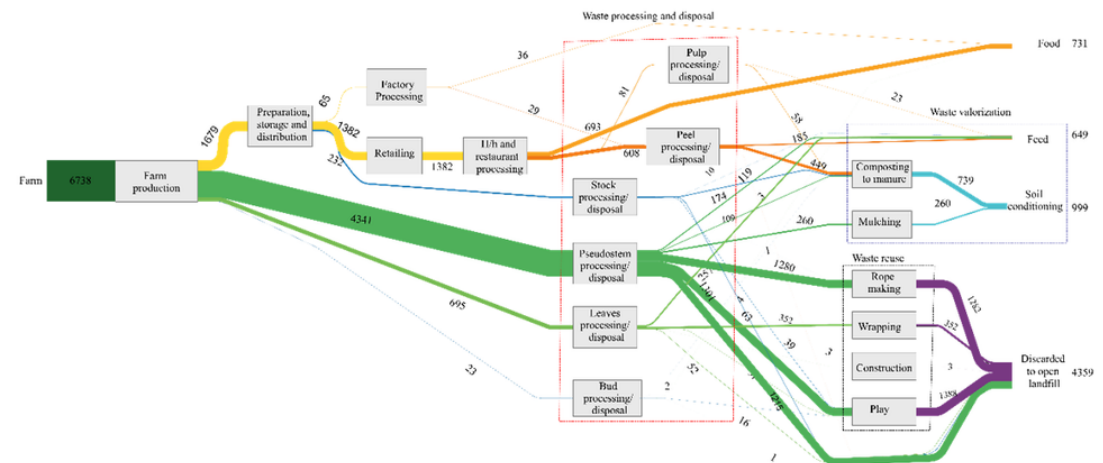

(a)

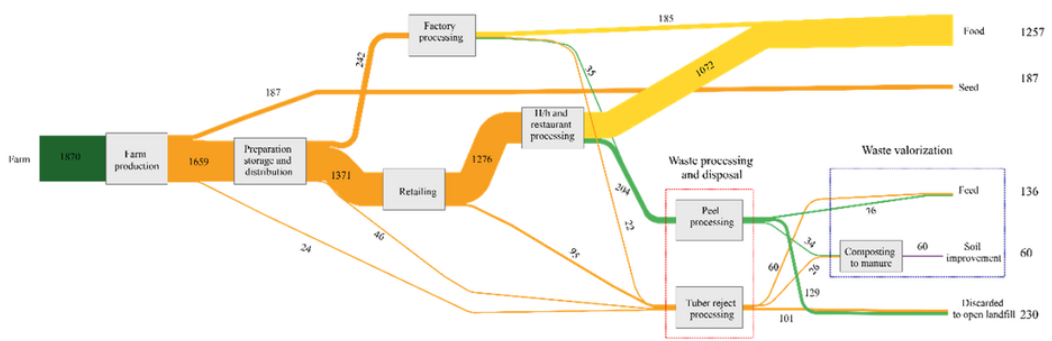

(b)

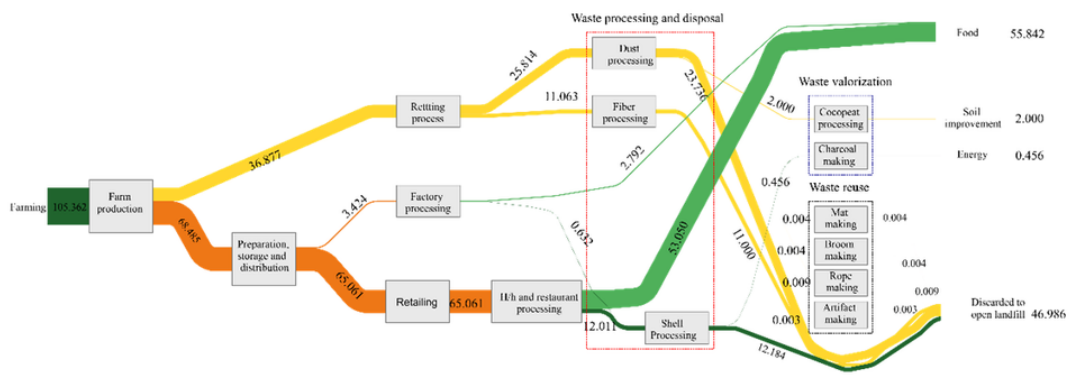

(c)

\section{Figure 3}

MFAdiagram of by-products in fresh weight basis (a) banana (kt), (b) potato (kt) and (c) coconut (t)

\section{Supplementary Files}

This is a list of supplementary files associated with this preprint. Click to download.

- GraphicalAbstract270821.docx

- Supplementarydoc270821.doc 